\title{
MEDIATION EFFECT OF VALUE ADDED INTELLECTUAL CAPITAL (VAIC) IN CORPORATE GOVERNANCE (CG) AND FINANCIAL PERFORMANCE RELATIONS
}

\author{
Kartika Hendra TItisari \\ Prodi Akuntansi, Fakultas Ekonomi, UNIBA Surakarta \\ kartikatitisari@yahoo.com
}

\begin{abstract}
This study aims to examine the relationship of Corporate Governance and Financial Performance with Intellectual Capital as a mediating variable with a sample of companies included in the chemical industry sector basis and the period of 2012 - 2014. The sampling method used in this research is purposive sampling. The data analysis procedures, structural equation modeling (SEM) with PLS Warp 4.0. The test results showed Corporate Governance affect the ROA. The greater the Corporate Governance further enhance the financial accountability of the company. Corporate Governance does not affect the Intellectual capital. Intellectual Capital affects the financial performance. Value added intellectual capital plays an important role in the performance of financial support the use of physical assets (fixed) to contribute to the company's performance. Although the model fit, but the results of the analysis of intellectual capital does not mediate the relationship Corporate Governance and Financial Performance. Suggestions for further research can be done in other sectors. It is quite possible in the banking sector, as it has done in several countries where the corporate governance affect the Intellectual capital.
\end{abstract}

Keywords: corporate governance, financial performance, intelectual capital.

\begin{abstract}
Abstrak
Penelitian ini bertujuan untuk menguji hubungan Corporate Governance dan Financial Performance dengan Intellectual Capital sebagai variabel mediasi dengan sampel perusahaan yang termasuk dalam sektor industri dasar dan kimia periode 2012 - 2014 dengan metode purposive sampling. Analisa data menggunakan structural equation modeling (SEM) dengan PLS Warp 4.0. Hasil penelitian menunjukkan Corporate Governance berpengaruh tethadap ROA. Semakin besar Corporate Governance meningkatkan akuntabilitas keuangan perusahaan. Selanjutnya Corporate Governance tidak berpengaruh terhadap Intellectual capital dan Intellectual capital berpengaruh terhadap financial performance. Value added intellectual capital memainkan peran penting dalam dukungan financial performance dan berkontribusi dalam penggunaan aset fisik (tetap) yang pada akhirnya meningkatkan kinerja perusahaan. Meskipun model fit, tetapi hasil analisis Intellectual capital tidak memediasi hubungan Corporate Governance dan financial performance. Saran untuk penelitian lebih lanjut dapat dilakukan di sektor lain. Sangat mungkin dilakukan pada sektor perbankan, seperti yang telah dilakukan di beberapa negara di mana Corporate Governance berpengaruh terhadap Intellectual Capital.
\end{abstract}


Kata Kunci: Corporate Governance, Financial Performance, Intelectual Capital. JEL: G0

\section{Research Background}

The influence of corporate governance towards financial performance became the topic of crucial research in both developed countries and developing countries. Corporation collapse due to a weak corporate governance system implies a need for improving and reforming governance structures. Companies that have a weak organizational structure become more vulnerable to fraud (Berkman 2009). Failure to prevent fraud has triggered many debates about the effectiveness of companies regarding rules, principles, structures and mechanisms (Sun 2011). Increasing corporate governance also impacts negatively on financial performance (Huang 2010, Hidalgo 2011, Nur'ainy 2013, Nuryaman 2015, Zabri 2015). Though, corporate governance is small but it has great impact on intellectual capital in banking companies in Australia (Joshi 2013). Intellectual enterprise capital has a positive impact on market value and financial performance (Chen 2006, Orens 2009 ).

This study examines the role of corporate governance in improving the company's financial performance. The consistency of the relationship between corporate governance and financial performance is the point. This study examines the role of intellectual capital as a mediating variable. The research conducts ROA in measuring financial performance.

Agency theory perspective is the basis used to understand corporate governance issues. The theory agency results in an asymmetrical relationship between owner and manager, to avoid a relationship that is asymmetry requires a concept that is the concept of Good Corporate Governance that aims to make the company healthier. The application of corporate governanc explains the relationship between management and the owner. Management as morally agents is responsible to optimize the benefits for the owner (principal) and the return will receive compensation in accordance with the contract

Shleifer and Vishny (1997) define Corporate governance concerns the way in which suppliers of funds and companies themselves ensure return on investment. The essence of Corporate Governance is to improve company performance through supervision and accountability management for other stakeholders based on the rules and regulations framework. The function of applying GCG (Daniri 2005) is decreasing agency fees, reducing capital costs (cost of capital), enhancing the value of shares of the company while enhancing the company's image in public for the long term, and supporting for stakeholders in the company environment.

Financial Performance is an important information for corporate stakeholders. The company's management performance has an impact on liquidity and stock price volatility, which is used as a basis by investors in investing (Junaedi 2005). In general, the traditional concept of business performance measurement (Fiori 2007) focus on the analysis: profitability, liquidity, solvency, financial efficiency, repayment capacity.

Bontis et al. (2000) state that in general, the researchers identified three main constructs of IC, namely: human capital (HC), structural capital (SC), and customer capital (CC). The method developed by (Pulic 1998), to present information about the value creation efficiency of tangible assets and intangible assets owned by the company. The VAIC TM method measures intellectual capital by calculating the value added resulting from three combinations of ratios, namely (1) Value Added Capital Employed (VACA) is an indicator of VA created by a unit of physical capital. (2) Value Added Human Capital (VAHU) shows the contribution made by each rupiah invested by human capital to the value added of human capital organizations representing individual knowledge stock of an organization represented 
by its employees (3) Structural Capital Value Added (STVA) amount of structural capital needed to produce 1 rupiah from VA and is an indication of how successful structural capital is in value creation.

Corporate Governance relates to the agency theory developed by Michael Johnson, a professor from Harvard considers that company management as 'agents' for shareholders will act with their own full awareness, not their responsibility to shareholders (Daniri 2005). Application of GCG in the company hold by the principles which have established. In general, GCG implementation consists of five basic principles, namely: transparency, accountability, responsibility, independence and justice. Through these principles, it is expected to improve Financial Performance. Many studies link these two variables with mixed results.

Huang (2010) found that an increase in independent outside directors, foreign institutional shareholders and domestic institutional shareholders has an effect on improving financial performance as measured by ROA. Zabri (2015) found that the size of the board of commissioners was significantly negative related to financial performance measured by ROA and ROE. While, the independent commissioner does not have relationship with the financial performance. Hidalgo (2011) found the ownership structure had a negative impact on intellectual capital in 100 companies traded on the Mexican Stock Exchange in 20052007. Nuryaman (2015) found intellectual capital has a positive effect on company value and air positive impact on profitability. Furthermore, the intellectual property of the company has a positive impact on market value and financial performance and can be indicators of future financial performance. Investor can place different values on the three components of value creation of efficiency (physical capital, human capital, and structural capital). $\mathrm{R} \& \mathrm{D}$ expenditures can provide additional information on structural capital and ownership positive effect on the value of the company and profitabilit as (Chen 2006). In European countries (Belgium, France, Germany and The Netherlands) capital intellectuals are positively related to company value (Orens 2009).

Empirical evidence presents corporate governance influence on financial performance with mixed results. Corporate governance has an effect on intellectual capital and intellectual capital affect on financial performance. This study will examine the effectof intellectual capital mediation on the effect of corporate governance to financial performance. The research hypothesis are $\mathrm{H} 1$ : corporate governance affect ROA; H2. corporate governance has an effect on intelectual capital; H3. intelectual capital has an effect on ROA; H4. intellectual capital mediates the effect of corporate governance against ROA.

The framework of the research concept is illustrated below:

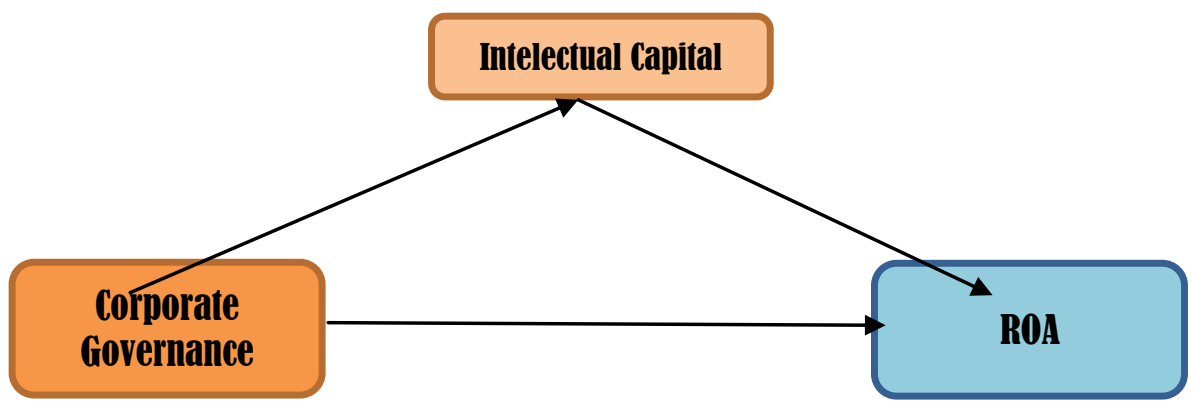

Figure 1. Research Concept Framework

\section{Research Method}

The population in this study is all the basic industrial and chemical manufacturing companies listed on the Indonesia Stock Exchange, during the period 2012-2014. The sampling 
method in this study use a purposive sampling method. The sample selection criteria in this study are: first, the basic industrial and chemical manufacturing companies that publish the company's annual report from 2012-2014. Second, manufacturing company that presents financial statements in rupiah. Third, manufacturing companies that have complete financial data and market data related to research. Fourth, The company did not obtain negative profits during the observation period.

This study uses measurements corporate governance from Said (2009). Hence, it is not used wholly and only uses the size of the board of directors, the size of the board of commissioners, and institutional ownership. Financial performance uses Return on Assets (ROA), which is the level of capability company in taking investment (Waddock and Graves 1997). Return on Assets = Net Income / Total Assets. The Intellectual Capital referred in this study is IC performance which is measured by the value added created by physical capital (VACA), human capital (VAHU), and structural capital (STVA). The combination of the three added values is symbolized by the name VAIC TM ( $\mathrm{P} \mathrm{u}$ lic, 1998). Data analysis is performed by using structural equation modeling (SEM) procedure with Warp PLS 4.0.

\section{Result and Discussion} ini:

Proses pemilihan sampel yang digunakan peneliti ditunjukkan pada Tabel 1 dibawah

Table 1. Sampling procedure

\begin{tabular}{lc}
\hline \multicolumn{1}{c}{ Information } & Total \\
\hline Manufacturing companies basic industrial and chemical sectors & 64 \\
Companies that do not meet the criteria & $(43)$ \\
Companies that meet the sample criteria & 21 \\
Total samples (2012-2014) & 63 \\
\hline
\end{tabular}

Source: primary data

Table 2. Companies that fulfill Research Sample Criteria

\begin{tabular}{ll}
\hline Code & \multicolumn{1}{c}{ Company name } \\
\hline INTP & PT Indocement Tunggal Prakarsa Tbk \\
SMCB & PT Holcim Indonesia Tbk \\
SMGR & PT Semen Indonesia (PERSERO) Tbk \\
AMFG & PT Asahimas Flat Glass Tbk \\
KIAS & PT Keramika Indonesia Association Tbk \\
TOTO & PT Surya Toto Indonesia Tbk \\
ALMI & PT Alumindo Light Metal Industri Tbk \\
HENNA & PT Indal Aluminum Industry Tbk \\
LION & PT Lion Metal Works Tbk \\
LMSH & PT Lionmesh Prima Tbk \\
PICO & PT Pelangi Indah Canindo \\
BUDI & PT Budi Starch \& Sweetener Tbk \\
INCH & PT Intanwijaya Internasional Tbk \\
SRSN & PT Indo Acidatama Tbk \\
AKPI & PT Argha Karya Prima Industry Tbk \\
IGAR & PT Champion Pacific Indonesia Tbk \\
TRST & PT Trias Sentosa Tbk
\end{tabular}




\begin{tabular}{|c|c|}
\hline CPIN & PT Charoen Pokphand Indonesia Tbk \\
\hline JPFA & PT Japfa Comfeed Indonesia Tbk \\
\hline SIPD & PT Sierad Produce Tbk \\
\hline ALDO & PT Alkindo Naratama Tbk \\
\hline
\end{tabular}

In the analysis process there are 3 data outliers, so that the data analyzed is 60 . From the output results, it shows the fit model, where the value of $\mathrm{P}$ value for Average Path Coefficient (APC) and Average R-squared (ARS) $<0.001$ with APC value $=0.297$ and ARS value $=$ 0.268. Likewise, the average blocks value of VIF (AVIF) and Average full collinearity VIF (AFVIF) <3.3, which means there are no problems with multicolonity between indicators and between latent variables. The result of GoF is $0.478>0.36$, which means that the model's fit is very good. Data analysis is done by a structural equation modeling (SEM) procedure.

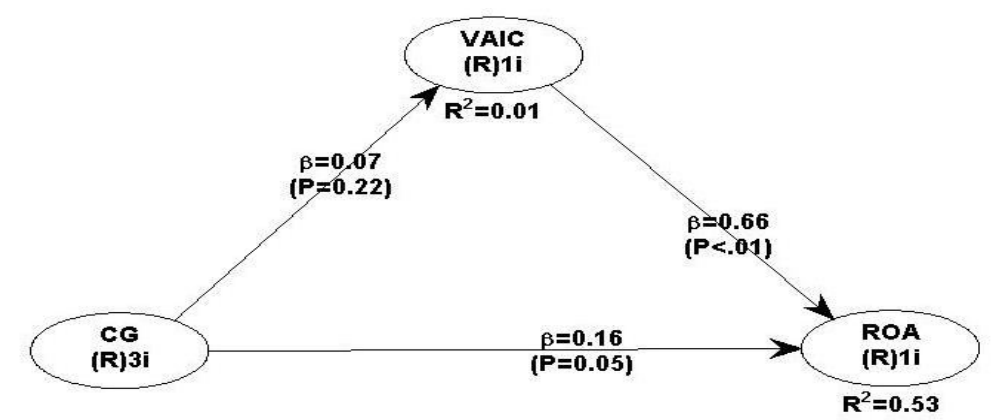

Figure 2. Relationship between CG, ROA, VAIC

The test results indicate that corporate governance has an effect on ROA. This is in line with the study (Huang 2010, Hidalgo 2011, Nuryaman 2015 ) and not in line with the research (Zabri 2015). The greater the number of boards of directors in the company will have a positive impact on financial performance, because the board of directors has carried out its functions by supervising the quality of financial reporting information provided to parties in need .The increasing number of board of commissioners increases supervision and control in corporate decision making. However, the increase in the number of board of directors and board of commissioners is certainly up to a certain amount. There will be difficulties in carrying out roles, if there are lots of directors and commissioners, including difficulties in coordinating and communicating the work of each board of commissioners themselves, difficulty controlling and overseeing management actions, and difficulties in making decisions that are useful for the company. Increasing number of institutional ownership will increase the behavior of the owner. Managers will act more carefully in carrying out company activities when institutional ownership experiences behavioral changes from passive to active which can increase managerial accountability. Furthermore, increasing in these things will improve financial performance.

Corporate governance does not affect intelectual capital, in line with research (Joshi 2013) in the banking sector. Intellectual capital has an effect on financial performance, in line with research (Chen 2006, Orens 2009). Mostly similar to the previous research conducted in the banking sector, the ability of resources to manage value added arises efficiently. So that, the amount of intellectual capital influences financial performance. Thus, intellectual capital value added plays an important role in financial performance along with the use of (fixed) physical assets that still dominate to contribute to the company's performance. The insignificant 
relationship between Corporate governance and Intellectual Capital means that there is no mediating role.

\section{Conclusion}

This study functioned to examine the influence corporate governance to financial performance with intellectual capital as mediating variables in a sample of companies included in the basic sectors and chemical industries period 2012 - 2014. The sampling method conducted in this research was purposive sampling. Data analysis was performed using structural equation modeling (SEM) procedure with Warp PLS 4.0. and to test the influence of mediation used a single test.

The test results showed that corporate governance had an effect on ROA. This was in line with the study (Huang 2010, Hidalgo 2011, Nuryaman 2015) and different from the research (Zabri 2015). Increasing the size of the board of directors, board size, and institutional ownership will improve the company's financial performance. However, this increase got a certain amount (Hidalgo 2011 ). Corporate governance had no effect on intellectual capital, in line with the research (Joshi 2013) and intelectual capital affect the financial performance, in line with the research (Chen 2006, Orens 2009). Value added intellectual capital took an important role in financial performance supporting the use of physical assets (fixed) to contribute to the performance of the company. Although the model was fit, the results of the analysis show intellectual capital was not mediate the influence of corporate governance to financial performance. Suggestions for further research can be done in other sectors. It is very possible in the banking sector, as has been done in several countries where corporate governance has an effect on intellectual capital .

\section{References}

Berkman H. 2009. Corporate governance, profit manipulation and stock return. Journal of International Business and Economics. 9(2): 132-145.

Chen MC. 2006. An empirical investigation of the relationship between intellectual capital and firms' market value and financial performance. Journal of Intellectual Capital. 6(2): 159-176.

Daniri MA. 2005. Good Corporate Governance - Konsep dan Penerapannya dalam Konteks Indonesia. Jakarta: Gloria Printing. .

Fiori. 2007. Corporate social responsibility and firms performance, an analysis Italian listed companies.

Hidalgo RL. 2011. Corporate Governance and Intellectual Capital Disclosure. Journal of Business Ethics. 100: 483-495

Huang CJ. 2010. Corporate governance, corporate social responsibility and corporate performance. Journal of Management \& Organization. 16(5).

Joshi M. 2013. Intellectual capital and financial performance: an evaluation of the Australian financial sector. Journal of Intellectual Capital. 14(2): 264-285.

Junaedi D. 2005. Dampak tingkat pengungkapan informasi perusahaan terhadap volume perdagangan dan return saham: penelitian empiris terhadap perusahaan-perusahaan yang tercatat di Bursa Efek Jakarta. Jurnal Akuntansi dan Keuangan Indonesia. 2(2): 1-28.

Nur'ainy R. 2013. Implementation of Good Corporate Governance and Its Impact on Corporate Performance: The Mediation Role of Firm Size (Empirical Study from Indonesia) . Global Business and Management Research: An International Journal. 5(2). 
Nuryaman. 2015. The Influence of Intellectual Capital on The Firm's Value with The Financial Performance as Intervening Variable. 2nd Global Conference on Business and Social Science. Bali: Indonesia.

Orens R. 2009. Intellectual capital disclosure, cost of finance and firm value. Management Decision. 47(10): 1536-1554.

Pulic A. 1998. Measuring the performance of intellectual potential in knowledge economy. The 2nd McMaster Word Congress on Measuring and Managing Intellectual Capital. Austrian.

Said R. 2009. The relationship between corporate social responsibility disclosure and corporate governance characteristics in Malaysian public listed companies. Social Responsibility Journal. 5(2): 212-226.

Shleifer A, Vishny RW. 1997. A survey of corporate governance. Journal of Finance. LII(2): 737-783.

Sun W. 2011. Corporate Governance and the Global Financial Crisis: International Perspectives. Cambridge: Cambridge University Press.

Waddock S, Graves, SM. 1997. The corporate social performancefinancial performance link. Strategic Management Journal. 18(4): 303-319.

Zabri SM. 2015. Corporate Governance Practices and Firm Performance: Evidence from Top 100 Public Listed Companies in Malaysia. 7th International Economics \& Business Management Conference. 